\title{
Liver Plays a Major Role in FGF-21 Mediated Glucose Homeostasis
}

\author{
Mingyao Liu ${ }^{\mathrm{a}}$ Hongwei Cao ${ }^{\mathrm{b}}$ Yuting Hou ${ }^{\mathrm{a}}$ Guopeng Sun ${ }^{\mathrm{a}}$ Deshan Lia \\ Wenfei Wanga \\ ${ }^{a}$ College of Life Sciences, Northeast Agricultural University, Harbin, ${ }^{b}$ College of Biological Science and \\ Technology, BaYi Agricultural University, DaQing, P.R. China
}

\section{Key Words}

Fgf-21 $\cdot$ Hepatocytes $\cdot$ Glucose metabolism $•$ GLUT1

\begin{abstract}
Background/Aims: The liver is a vital organ in vertebrates and has a wide range of functions, including glucose absorption, glycogen storage and glucose production. Fibroblast growth factor (FGF)-21 is a metabolic regulator that is primarily produced by the liver. In this paper, we studied the effect of FGF-21 on glucose metabolism in the liver. Methods: The glucose uptake of cells was detected by 2-Deoxy- $\mathrm{d}-\left[{ }^{3} \mathrm{H}\right]$ glucose; the synergy between insulin and FGF-21 was evaluated. The mRNA expression of GLUT1-4, G6Pase and PEPCK was detected by real-time PCR. Glycogen synthesis was examined by the anthrone method. Blood samples to monitor glucose in $\mathrm{db} / \mathrm{db}$ diabetic mice were obtained by tail snip. Glucose metabolism in the liver and adipose tissues was observed by fluorescence microscopy. Results: In this study, FGF-21 stimulated glucose uptake by liver cells in both a dose and time-dependent manner, and at the same time, FGF-21 specifically stimulated GLUT1 expression in the liver cells. Furthermore, FGF-21 demonstrated a synergistic effect with insulin on glucose absorption, which is in accordance with enhanced GLUT-1 and -4 expression. Treatment with FGF-21 increased glycogen storage in liver cells. Consistent with in vitro results, FGF-21 lowered the plasma glucose level and stimulated GLUT1 expression and glycogen synthesis in $\mathrm{db} / \mathrm{db}$ diabetic mice. Simultaneously, FGF-21 inhibited the gene expression of G6Pase and PEPCK. Conclusion: Our results suggest that FGF-21 clears up plasma glucose by stimulating glucose absorption in the liver of diabetic animals and decreases glucose release from the liver by inhibiting gluconeogenesis. Overall, these data indicate that the liver is an important target organ of FGF-21 to regulate glucose metabolism.

\section{Introduction}

Fibroblast growth factor 21 (FGF-21) is a metabolic regulator of glucose and lipid homeostasis and is implicated as a potential therapeutic reagent for diabetes [1,2], nonalcoholic fatty liver disease (NAFLD) [3], obesity [4] and other metabolic disorders [5-8]. 
Kharitonenkov et al. [1]. first studied the function of FGF-21 and showed that FGF-21 enhances glucose uptake in 3T3-L1 adipocytes through the upregulation of glucose transporter-1 (GLUT1) expression. In vivo, FGF-21 transgenic mice are resistant to diet-induced weight gain and fat accumulation, having significantly lower levels of glucose in fasting conditions compared to the control group. When FGF-21 is administered to diabetic mice and nonhuman primates, it provides an effective and sustained control over blood glucose and lipids $[1,2]$. FGF-21 preserves the mass and function of $\beta$-cells [9], improves insulin sensitivity [10], and ameliorates lipoprotein profiles including an increase and decrease in the high and low-density lipoprotein, respectively, as well as by other beneficial changes [11]. In addition, other studies showed that adipose tissue is not an exclusive target of FGF-21, and FGF-21 plays a valuable role in hepatic steatosis in diet-induced obese mice $[12,13]$ as well. Li et al. [3] showed that serum FGF-21 can be potentially used as a biomarker for non-alcoholic fatty liver disease in humans. Taken together, these findings demonstrate that the liver is a target organ of FGF-21 that has a potent regulatory role in hepatic lipid metabolism [3, 12-14].

The liver is one of the most important organs in vertebrates, which plays a central role in regulating whole body metabolism, including glucose and lipids [15]. The most important role of the liver in glucose homeostasis is to maintain a stable fast blood glucose level in the fasting state through gluconeogenesis, glycogenolysis and glycogen synthesis. Deregulation between glucose uptake and production by the liver is thought to contribute to the onset of type 2 diabetes $[16,17]$. Although FGF-21 has been implicated in the regulation of hepatic function $[6,14,18-21]$, no direct evidence has been found showing the effect of FGF-21 on regulation of glucose uptake in hepatic cells. We hypothesized that FGF-21 regulates plasma glucose via its beneficial effects on glucose uptake and production by the liver. To prove this, we chose the HepG2 cell model and mouse primary hepatocytes to study the effect of FGF-21 on liver glucose regulation in vitro. In vivo, chronic administration of FGF-21 in db/ $\mathrm{db}$ diabetic mice was performed to explore the relationship between glucose metabolism in the liver and plasma glucose. We detected the changes in glycogen synthesis and gene expression of key enzymes induced by FGF-21 to study the mechanism of FGF-21 activity. In conclusion, our data suggest that FGF-21 regulates plasma glucose by regulating GLUT1, stimulates glycogen synthesis, and inhibits gluconeogenesis in the liver.

\section{Materials and Methods}

Ethics statement: The animal protocols were approved by the Heilongjiang animal care and use committee.

\section{Materials}

HepG2 cells were obtained from American Type Culture Collection (ATCC). Human recombinant insulin was purchased from Sigma-Aldrich (St. Louis, MO, USA). Cell culture media and blood serum were obtained from Invitrogen Corporation (Gaithersburg, USA). 2-Deoxy- $d-\left[{ }^{3} \mathrm{H}\right]$ glucose was obtained from China Isotope Corporation. 2-[N-(7-nitrobenz-2-oxa-1, 3-diazol-4-yl) amino] -2-deoxy-D-glucose (2-NBDG) was obtained from Invitrogen Corporation. All other reagents were commercially available and of highest purity grade.

Expression and purification of mouse FGF-21

The FGF-21 cDNA was prepared from mouse liver. The FGF-21 protein was expressed and purified by Sumo expression as previously described [22].

Cell cultures and glucose uptake assay

Primary hepatocytes were isolated from Kunming mice using a collagenase perfusion method [23] and seeded onto collagen-coated 24-well plates. The hepatocytes were grown in DMEM containing 10\% FBS, 100 units $/ \mathrm{ml}$ of penicillin and $100 \mu \mathrm{g} / \mathrm{ml}$ of streptomycin supplemented with $10 \mu \mathrm{g} / \mathrm{ml}$ insulin. The HepG2 cells were planted onto 96-well plates and cultured with DMEM containing 10\% NBCS. For glucose uptake assay, primary hepatocytes and HepG2 cells were serum starved for $12 \mathrm{~h}$, and the cells were treated with different concentrations of FGF-21 $(0,0.1,1,10,100,1000 \mathrm{nM})$ for $24 \mathrm{~h}$. The plain medium was used as blank control. To detect the cumulative action of insulin and FGF-21, HepG2 cells were co-treated with 
$1 \mathrm{nM}$ FGF-21 and different concentrations of insulin $(0,0.01,0.1,1,10,100,1000 \mathrm{nM})$ for $24 \mathrm{~h}$. Cells were washed twice in KRP buffer $\left(136 \mathrm{mM} \mathrm{NaCl}, 4.7 \mathrm{mM} \mathrm{KCl}, 1.25 \mathrm{mM} \mathrm{CaCl}_{2}, 1.25 \mathrm{mM} \mathrm{MgSO}_{4} \times 7 \mathrm{H}_{2} \mathrm{O}\right.$, and $10 \mathrm{mM}$ HEPES, pH 7.4) and $100 \mu \mathrm{l}$ of 2-Deoxy-d-[ $\left[{ }^{3} \mathrm{H}\right]$ glucose $(0.1 \mu \mathrm{Ci} / \mathrm{ml}, 0.1 \mathrm{mM})$ was added for $10 \mathrm{~min}$ at $37^{\circ} \mathrm{C}$. Finally, cells were washed three times with ice-cold KRP buffer, lysed in $1 \mathrm{M} \mathrm{NaOH}$, and the cell-associated radioactivity was counted using liquid scintillation counter. Aliquots of cell lysates were further used for the determination of protein content by a BCA Protein Assay Kit.

\section{Animals and treatments}

Male $\mathrm{db} / \mathrm{db}$ mice were obtained from Shanghai Slac Laboratory Animal Co. Ltd. They were housed at $21 \pm 2{ }^{\circ} \mathrm{C}$ in a $12 \mathrm{~h}$ light/dark cycle and had free access of food and water. Blood samples for monitoring glucose were obtained by tail snip. The mice were randomly assigned to treatment and vehicle groups regardless of their glucose levels and body weights. Four groups of $\mathrm{db} / \mathrm{db}$ mice were injected intraperitonally (ip) once daily with vehicle ( $0.9 \%$ saline), $4 \mathrm{U}$ insulin (Sigma), $0.5 \mathrm{mg} / \mathrm{kg}$ FGF-21, or a mixture of $0.125 \mathrm{mg} /$ kg FGF-21 and 4U insulin for 8 consecutive weeks. Mice were maintained on a standard diet and plasma glucose was monitored during the period of drug treatment. Fed glucose was determined after $1 \mathrm{~h}$ of drug administration on $0,1,2,3,4,5,6,7$ days. Then mice were fasted for $10 \mathrm{~h}$ and fasting glucose after $1 \mathrm{~h}$ drug administration on $2,12,22,32,42$ days were detected.

\section{Determination of 2-NBDG in liver and adipose tissue}

Mice were injected intraperitoneally (ip) once daily with $0.5 \mathrm{mg} / \mathrm{kg}$ FGF-21 for 8 consecutive weeks. Mice were fasted for $2 \mathrm{~h}$ before FGF-21 administration and then subcutaneously injected with 2-NBDG (250 $\mu \mathrm{g} /$ mice). Blood samples were collected from the tails at 0,30,60 min after glucose loading to determine the glucose concentrations. Mice were sacrificed by cervical dislocation 60 min after 2-NBDG injection. The liver and epididymal adipose tissue were immediately fixed in $4 \%$ formaldehyde for $16 \mathrm{~h}$ before paraffin embedding. The paraffin-embedded tissues were cross-sectioned ( $6 \mu \mathrm{m}$ thickness) stepwise and the fluorescent sections were analyzed by fluorescence microscopy.

\section{Extraction of RNA, cDNA synthesis and real-time PCR}

Total RNA was prepared from the cells and liver samples using Trizol reagent (Invitrogen Corporation, Carlsbad, CA) in accordance with the manufacturer's instructions. Total RNA ( $2 \mu \mathrm{g})$ was reverse-transcribed by oligodT18 (Takara) using SuperScript First-Strand Synthesis System (Invitrogen Corporation). The target cDNAs were analyzed by real-time PCR with QuantiTest SYBR Green PCR kit (Takara) using ABI 7300 (Applied Biosystems, Foster City, CA) according to the protocols provided by the manufacturer. All primer sequences $[24,25]$ are presented in Table 1.

\section{Detection of glycogen content}

After treatment with $100 \mathrm{nM} \mathrm{FGF-21}$ and $100 \mathrm{nM}$ insulin alone or in combination for $24 \mathrm{~h}$, the HepG2 cells were washed twice with PBS and resupended in $0.5 \mathrm{ml}$ media. The stimulated cells were adjusted to a concentration of approximately $10^{5}$ cells $/ \mathrm{ml}$. Liver samples were washed twice with normal saline and 200 $\mathrm{mg}$ of liver tissue was homogenized in $4 \mathrm{ml}$ of 5\% TCA for $1 \mathrm{~min}$. All samples were centrifuged at $3000 \mathrm{rpm}$ for $15 \mathrm{~min}$. The precipitate was dissolved in 5\% TCA and centrifuged once again. $1 \mathrm{ml}$ of the supernatant was mixed with $4 \mathrm{ml}$ of $95 \%$ ethanol. After incubating overnight at the room temperature, the mixture was centrifuged at $3000 \mathrm{rpm}$ for $15 \mathrm{~min}$. The resultant white precipitate was washed once with $95 \%$ ethanol and then dissolved in water. Glycogen contents were examined by anthrone method [26].

\section{Statistical analysis}

Data were represented as mean $\pm \mathrm{SE}$, and all experiments were repeated at least with three batches of samples. All data were tested for significance using ANOVA, and results with $* \mathrm{P}<0.05$ and $* * \mathrm{P}<0.01$ were considered as statistically significant.

Table 1. Primer sequences for real-time PCR

\begin{tabular}{lcc}
\hline Genes & Sense primer & Antisense primer \\
\hline GLUT1(HepG2) & CATCAATGCCCCCCAGAA & AAGCGGCCCAGGATCAG \\
GLUT4(HepG2) & CTGGGCCTCACAGTGCTAC & GTCAGGCGCTTCAGACTCTT \\
GAPDH(HepG2) & GGAAGGTGAAGTCGGAGTC & ACTCCACGACGTACTCAGCG \\
GLUT1 & CCATCCACCACACTCACCAC & GCCCAGGATCAGCATCTCAA \\
GLUT4 & CCTTTGAGATTGGCCTGG & AGGTGAAGATGAAGAAGCCAAGC \\
GK & GGAGACCAGCCCTTTAAGCT & GTCCACTGCTCCCACCAATG \\
G6Pase & TCAACCTCGTCTTCAAGTGGATT & GCTGTAGTAGTCGGTGTCCAGGA \\
PEPCK & GGCGGAGCATATGCTGATCC & CCACAGGCACTAGGGAAGGC \\
$\beta$-actin & GAGACCTTCAACACCCC & GTGGTGGTGAAGCTGTAGCC \\
\hline
\end{tabular}




\section{Results}

\section{FGF-21 induces glucose uptake in liver cells}

The HepG2 cell model was chosen to model the liver, which is considered to retain most of the functions of glucose metabolism and lipid metabolism. Asrih et al. found that FFA impairs the effect of FGF21 on hepatic lipid metabolism in HepG2 cells [27]; however, the direct effect of FGF-21 on glucose metabolism in HepG2 cells has not been fully examined. To evaluate whether FGF-21 stimulates glucose metabolism in the liver, glucose uptake assays were carried out in HepG2 cells and mouse primary hepatocytes. After treatment with FGF21 , glucose consumption in both cell types was significantly increased in a dose-dependent manner (Fig. 1A and B), suggesting that both cell types responded to FGF-21 treatment. To test whether FGF-21 displays a synergistic effect with insulin as previously reported in adipocytes [28], HepG2 cells were treated with either FGF-21 or insulin alone or co-treated with fixed FGF-21 and variable amounts of insulin. The results showed that both proteins could stimulate glucose consumption of HepG2 cells in a dose-dependent manner. However, compared to either FGF-21 or insulin treatment alone, co-treatment of HepG2 cells with both proteins significantly enhanced glucose uptake (Fig. 1C), suggesting that FGF-21 could enhance the effect of insulin.

\section{FGF-21 stimulates glucose uptake by HepG2 cells in a time-dependent manner}

The effect of FGF-21 on glucose uptake with time in liver cells was evaluated by measuring 2-Deoxy-d-[3 $\left.{ }^{3}\right]$ glucose incorporation in HepG2 cells at 2, 4, 6, 8, 12, 24 and 36 $\mathrm{h}$ after $100 \mathrm{nM}$ FGF-21 treatment. The results showed that the effect of FGF-21 on glucose

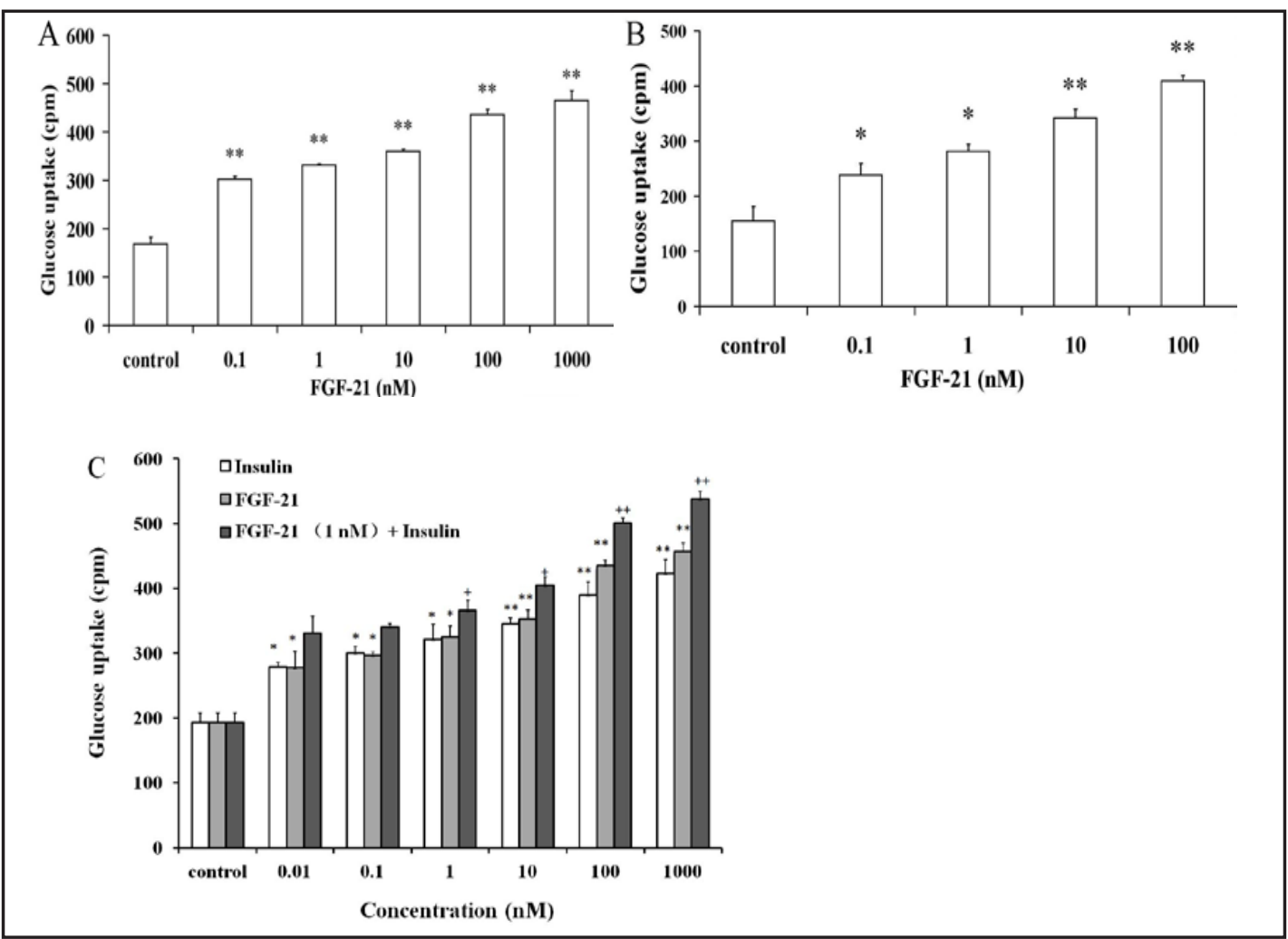

Fig. 1. FGF-21 stimulates glucose uptake and shows a synergistic effect with human recombinant insulin in liver cells. FGF-21 dose response on HepG2 (A) and primary hetapocytes (B) in glucose uptake assay. (C) FGF-21 shows synergistic effect with insulin. HepG2 cells were treated with insulin and FGF-21 alone or cotreated with fixed FGF-21 (1 nM) and variable doses $(0.01,0.1,1,10,100,1000 \mathrm{nM})$ of insulin. The values $( \pm$ SE) shown are the average of at least 3 independent experiments. ${ }^{*} \mathrm{P}<0.05,{ }^{* *} \mathrm{P}<0.01$ compared to unstimulated control (t-test). ${ }^{+} \mathrm{P}<0.05,{ }^{++} \mathrm{P}<0.01$ compared to insulin or FGF-21 treatment alone (t-test). 
uptake was observed after 4 h of treatment in HepG2 cells, and the cells stimulated with FGF21 showed enhanced glucose uptake compared to the cells treated with $100 \mathrm{nM}$ insulin for 8 h (Fig. 2). The predominant effect of FGF-21 on glucose uptake in liver cells was sustained up to $36 \mathrm{~h}$. These results strongly indicated that the effect of FGF-21 on stimulation of glucose uptake in HepG2 cells was time-dependent in nature.

Increase in GLUT1 mRNA level in liver cells contributes to glucose uptake stimulated by FGF-21

Glucose uptake in HepG2 cells was affected by FGF-21 after $4 \mathrm{~h}$ of treatment, suggesting that transcriptional and translational activation were both involved. GLUT1 has been shown as an important player for FGF-21-induced glucose uptake in adipocytes. However, GLUT1 to GLUT4 all exist in hepatocytes and GLUT2 is the main glucose transporter stimulated

Fig. 2. FGF-21 stimulates glucose uptake by HepG2 cells in a time-dependent manner. HepG2 cells were treated with $100 \mathrm{nM}$ human recombinant insulin and 100 nM FGF-21 respectively for different length of times $(\mathrm{h})$. The values $( \pm \mathrm{SE})$ shown are the average of at least 3 independent experiments. ${ }^{*} \mathrm{P}<0.05,{ }^{* *} \mathrm{P}<0.001$ compared to unstimulated control. ${ }^{+} \mathrm{P}<0.05,{ }^{++} \mathrm{P}<0.01$ compared to human recombinant insulin treated cells.
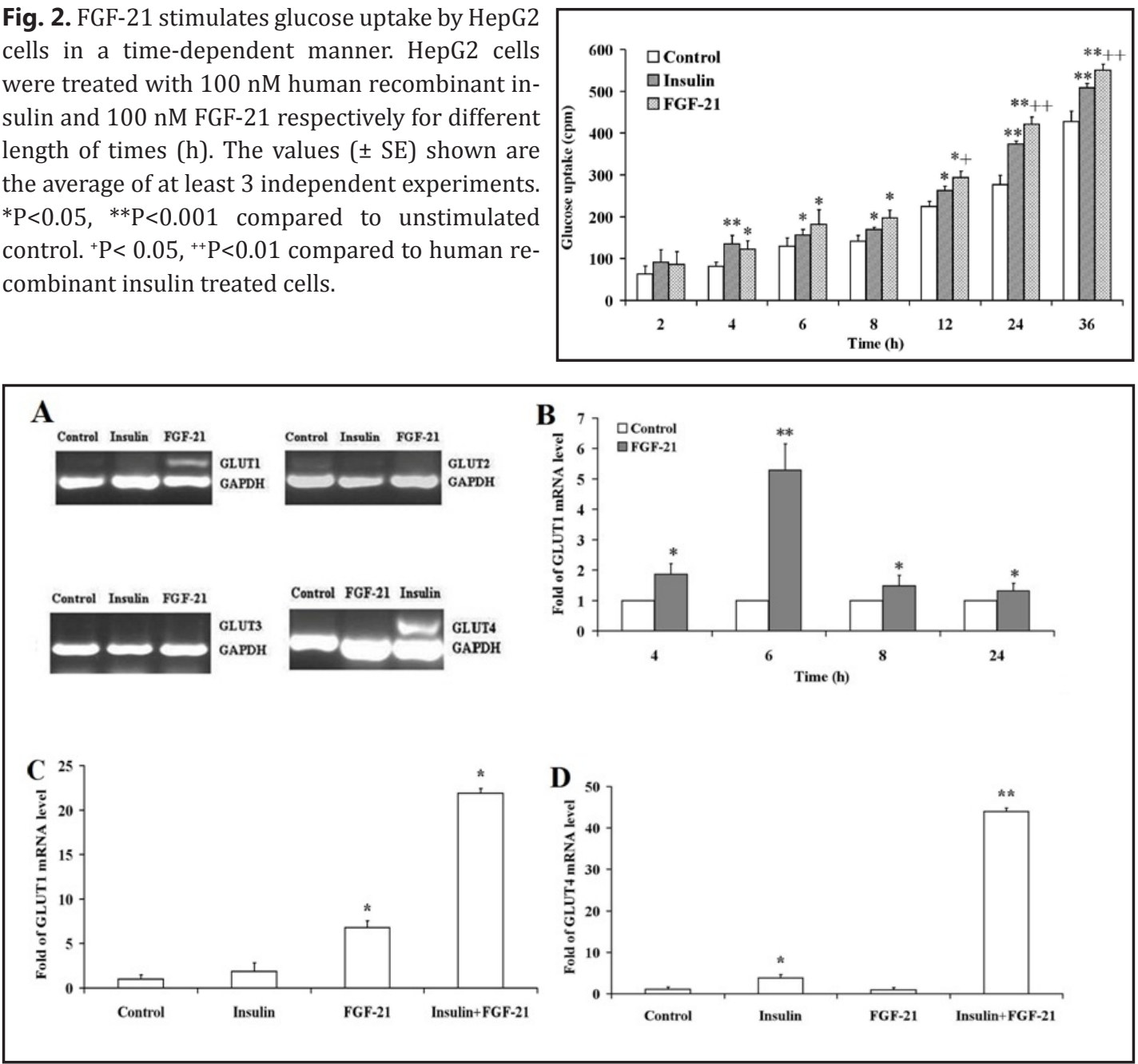

Fig. 3. FGF-21 enhances GLUT1 expression without any effect on GLUT2, GLUT3 and GLUT4 in HepG2 cells. (A) FGF-21 specifically regulated GLUT1 mRNA expression in HepG2 cells. HepG2 cells were stimulated by $100 \mathrm{nM}$ FGF-21 or $100 \mathrm{nM}$ insulin for $6 \mathrm{~h}$ and mRNA expression was determined by semiquantitative PCR. (B) mRNA expression of GLUT1 by real-time PCR reached the highest peak at 6 hours stimulated by $100 \mathrm{nM}$ FGF-21 in HepG2 cells. (C) and (D) mRNA expression of GLUT1 and GLUT4 stimulated by FGF-21 and insulin may help in understanding the synergistic effect of FGF-21 and insulin on glucose uptake. HepG2 cells were stimulated by $100 \mathrm{nM} \mathrm{FGF-21}$ or $100 \mathrm{nM}$ insulin alone or co-treated with both. Real-time PCR analyses were used to measure mRNA levels. The values $( \pm$ SE) shown are the average of at least 3 independent experiments. ${ }^{*} \mathrm{P}<0.05,{ }^{* *} \mathrm{P}<0.001$ compared to unstimulated control. 
by plasma glucose [29]. To explore the mechanism of action of FGF-21 on glucose uptake by hepatocytes, mRNA was extracted from HepG2 cells and incubated with or without 100 nM FGF-21. Gene specific primer sets were then used for amplification of GLUT1, GLUT2, GLUT3 and GLUT4. The results showed that only the GLUT1 mRNA level in HepG2 cells increased with FGF-21 stimulation, whereas GLUT4 mRNA increased with $100 \mathrm{nM}$ insulin stimulation, as expected (Fig. 3A). To study the relationship between FGF-21 and GLUT1 mRNA expression, real-time PCR was used for quantitation of the GLUT1 mRNA expression level. The results demonstrated that GLUT1 mRNA expression in HepG2 cells was increased more than 5-fold at $6 \mathrm{~h}$ post treatment with $100 \mathrm{nM} \mathrm{FGF-21,} \mathrm{compared} \mathrm{to} \mathrm{the} \mathrm{unstimulated}$ control (Fig. 3B). Altogether, these data suggested that FGF-21 induced GLUT1 expression to transport the basal glucose in the liver cells. Further, we detected the combined effect of insulin and FGF-21 on glucose transporters. Excitingly, compared to $100 \mathrm{nM} \mathrm{FGF-21}$ and 100 $\mathrm{nM}$ insulin treatment alone at $6 \mathrm{~h}$, the levels of GLUT1 and GLUT4 mRNA were increased significantly with insulin and FGF-21 co-treatment (Fig. 3C, Fig. 3D). These results suggested that FGF-21 and insulin might regulate the expression of glucose transporters in the liver cells through a synergistic effect.

\section{FGF-21 stimulates liver cells to store glycogen}

One of the important functions of the liver is glycogen synthesis. To detect whether FGF-21 stimulates glycogen storage in HepG2 cells, a colorimetric reaction by anthrone was used to detect glycogen synthesis. The results showed that glycogen synthesis was markedly increased in HepG2 cells treated with $100 \mathrm{nM} \mathrm{FGF-21}(P<0.05)$ or $100 \mathrm{nM}$ insulin $(P<0.01)$. A cumulative effect of FGF-21 and insulin on glycogen synthesis was observed (Fig. 4), which was consistent with the synergistic effect on glucose uptake in the liver cells after cotreatment. The results suggested that FGF-21 stimulates glucose uptake by liver cells to store glycogen and might have a co-regulatory effect with insulin.

Detection of glycometabolism stimulated by FGF-21 in the livers of $d b / d b$ mice with fluorescent imaging

A fluorescent analogue of 2-deoxyglucose, 2-[N-(7-nitrobenz-2-oxa-1, 3-diazol-4-yl) amino]-2-deoxy-D-glucose (2-NBDG) can be taken up by live cells and be phosphorylated. Phosphorylated 2-NBDG cannot be metabolized and can thus be detected by fluorescence microscopy. In this study, 2-NBDG was used to assess glucose transport stimulated by FGF-21. After 60 min of 2-NBDG injection, the plasma glucose of $\mathrm{db} / \mathrm{db}$ mice was lowered near to a normal level with $0.5 \mathrm{mg} / \mathrm{kg} \mathrm{FGF}-21$ injection. After sacrificing the mice, glucose metabolism in the liver and adipose tissues was observed by fluorescence microscopy. The results showed that 2-NBDG was taken up by both the liver and epididymal adipose tissue (positive control) when stimulated with FGF-21 in db/db mice (Fig. 5). The fluorescent images suggested that FGF-21 could regulate glucose transport in liver cells in vivo.

FGF-21 stimulates glycogen synthesis and inhibits gluconeogenesis by the liver for regulation of plasma glucose homeostasis in diabetic mice

FGF-21 regulates plasma glucose in vivo, which was first reported by Kharitonenkov et al. in 2005 [1]. However, to date, the mechanism of action of FGF-21 has not been fully understood.

Fig. 4. FGF-21 stimulates glycogen synthesis in HepG2 cells. Cells were incubated with FGF-21 or insulin alone or co-treated with both $(100$ $\mathrm{nM}$ ) for $24 \mathrm{~h}$. Glycogen content was detected with anthrone. The values $( \pm \mathrm{SE}$ ) shown are the average of at least 3 independent experiments. ${ }^{*} \mathrm{P}<0.05,{ }^{*} \mathrm{P}<0.01$ compared to unstimulated control. ${ }^{+} \mathrm{P}<0.01$ compared to $100 \mathrm{nM}$ FGF-21 or $100 \mathrm{nM}$ insulin treatment alone.

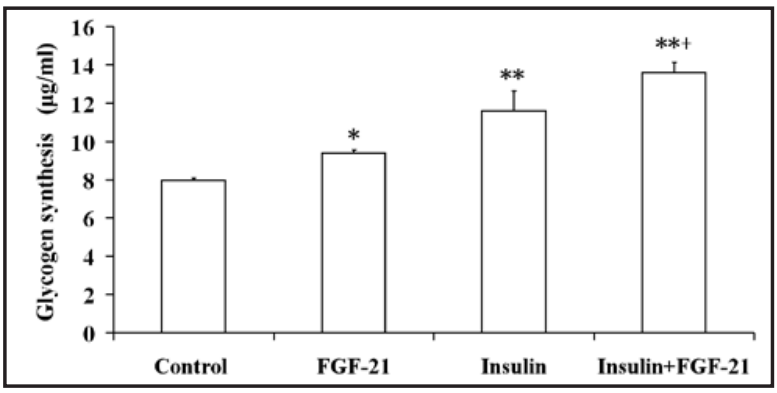




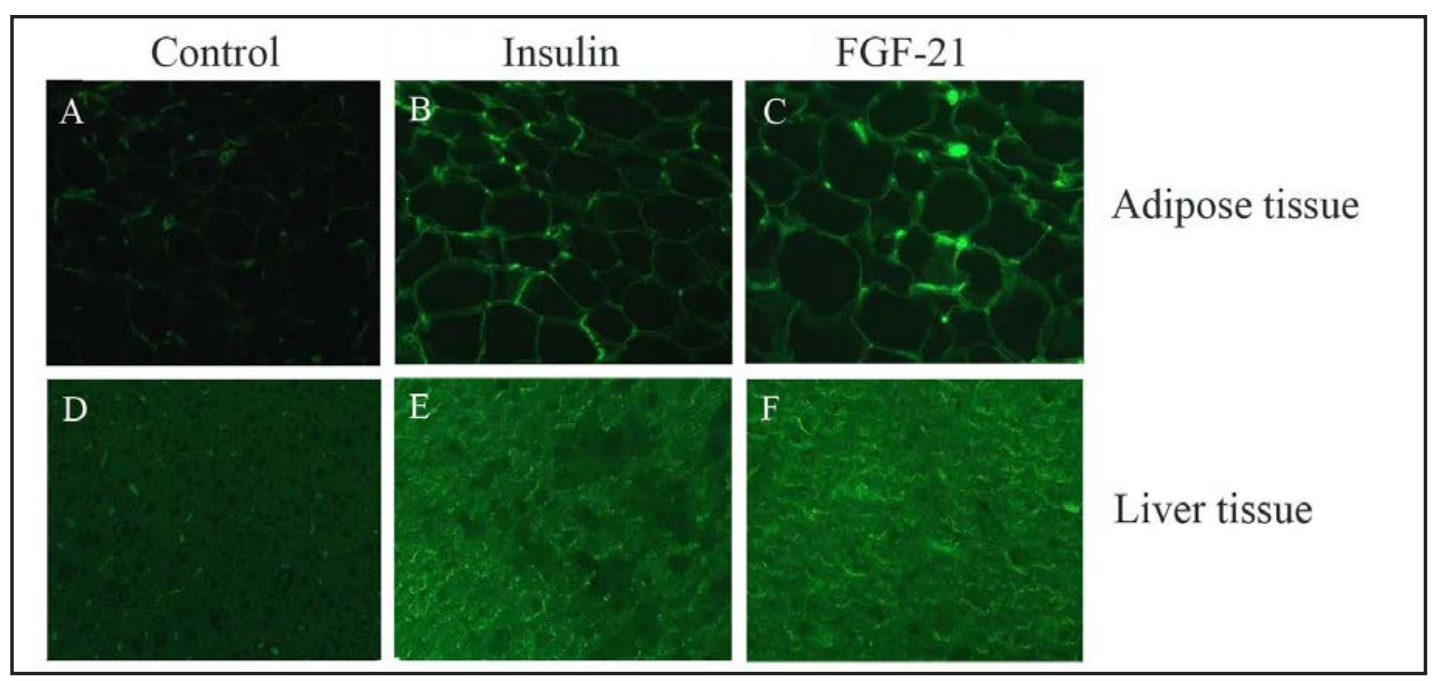

Fig. 5. FGF-21 stimulates glucose transport in the livers of $\mathrm{db} / \mathrm{db}$ mice. Male $\mathrm{db} / \mathrm{db}$ mice were injected intraperitonally (ip) once daily with $0.9 \%$ saline (A, D), 4 U insulin (B, E) or $0.5 \mathrm{mg} / \mathrm{kg} \mathrm{FGF-21} \mathrm{(C,} \mathrm{F)} \mathrm{for} 8$ consecutive weeks. Mice were fasted for $2 \mathrm{~h}$ before FGF-21 administration and then subcutaneously injected with 2-NBDG (250 $\mu \mathrm{g} /$ mice). 2-NBDG transport of in vivo was obseved by fluorescence microscopy as described in Materials and Methods. (A) and (D), Shown are images of phosphorylated 2-NBDG in adipose tissue and in liver tissue in control. (B) and (E), Shown are fluorescence enhancement images of 2-NBDG transport in adipose tissue and in liver tissue that were stimulated with insulin in positive control. (C) and (F), Fluorescent images suggest that FGF-21 stimulated 2-NBDG transport both in adipose tissue and in liver tissue.

To elucidate the role of the liver in glucose metabolism of diabetic mice administered with FGF-21, we measured glycogen content and the gene expression of GK, G6Pase, and PEPCK in $\mathrm{db} / \mathrm{db}$ mice. These mice were administered FGF-21 protein for 8 consecutive weeks, and plasma glucose was monitored daily. The results demonstrated that, after 1 day, the glucose levels in $\mathrm{db} / \mathrm{db}$ mice were significantly lowered with the administration of $0.5 \mathrm{mg} / \mathrm{kg} / \mathrm{d}$ of FGF-21 $(P<0.05$, Fig. 6A). After 4 days of injection, the glucose levels of $\mathrm{db} / \mathrm{db}$ mice were lowered to a normal level. Remarkably, FGF-21 also regulated the fasting glucose in $\mathrm{db} / \mathrm{db}$ mice (Fig. 6B) and glucose remained at normal levels up to $24 \mathrm{~h}$ after withdrawal of FGF21 (Fig. 6C). This led us to hypothesize that FGF-21 acted on the regulation of the glucose level and might have a connection with hepatic glucose metabolism. We also examined the synergistic effect of FGF-21 and insulin on glucose regulation in vivo. The $\mathrm{db} / \mathrm{db}$ mice had a minor change in glucose levels after $24 \mathrm{~h}$ of administration of $0.125 \mathrm{mg} / \mathrm{kg}$ of FGF-21 or $4 \mathrm{U}$ insulin (Fig. 6A). In contrast, the glucose levels of $\mathrm{db} / \mathrm{db}$ diabetic mice were significantly lowered after 1 day of administration of $0.125 \mathrm{mg} / \mathrm{kg} \mathrm{FGF-21}$ and $4 \mathrm{U}$ insulin mixture $(P<0.01$, Fig. 6A). These data suggested that FGF-21 combined with insulin can regulate plasma glucose much faster and can maintain glucose homeostasis for a prolonged period of time, compared to insulin administration alone. No evidence of hypoglycemic mice was observed during the 8 weeks of treatment with FGF-21.

Glucose production in the liver ensures a sufficient supply of glucose for the body in the post-absorptive state, and at the same time, glycogen is stored by taking up a portion of ingested carbohydrates in the post-prandial period [15].To investigate the mechanism of regulation of plasma glucose by FGF-21, we measured glycogen content and mRNA levels of some enzymes involved in the glycolysis and gluconeogenesis in the liver of $\mathrm{db} / \mathrm{db}$ diabetic mice. The results showed that both FGF-21 $(0.05 \mathrm{mg} / \mathrm{kg})$ and the mixture of FGF-21 $(0.125$ $\mathrm{mg} / \mathrm{kg}$ ) and insulin (4U) could significantly increase glycogen synthesis, compared to that in the control (Fig. 6D). The real-time PCR results showed that FGF-21 reduced mRNA expression of GK, G6Pase and PEPCK in the livers of db/db mice (Fig. 6E), suggesting that FGF-21 regulates glucose release by inhibiting gluconeogenesis in the liver. We also detected 
Fig. 6. FGF-21 regulates plasma glucose in diabetic mice stimulating glycogen synthesis and inhibiting gluconeogenesis in the liver tissue. (A) Fed blood glucose levels in $\mathrm{db} / \mathrm{db}$ mice treated with FGF-21. (B) Fasted glucose levels in $\mathrm{db} / \mathrm{db}$ mice during 8-weeks of constant-infusion study. (C) Glucose fluctuation within $24 \mathrm{~h}$ in $\mathrm{db} / \mathrm{db}$ mice was detected at the end of 8 consecutive weeks of FGF-21 treatment. (D) FGF-21 increased glycogen contents in $\mathrm{db} / \mathrm{db}$ mice after 8-weeks of injection study. The hepatic glycogen synthesis of $\mathrm{db} / \mathrm{db}$ mice after administered with $4 \mathrm{U}$ insulin, low-dose FGF-21 $(0.125$ $\mathrm{mg} / \mathrm{kg}$ ) and $4 \mathrm{U}$ insulin co-treatment, medium-dose FGF-21 $(0.5 \mathrm{mg} / \mathrm{kg})$ respectively. (E) FGF-21 enhanced mRNA levels of GLUT1 and reduced the gene expressions of GK, G6Pase and PEPCK in $\mathrm{db} / \mathrm{db}$ mice. Total RNA were extracted from liver samples of $\mathrm{db} / \mathrm{db}$ mice injected with $0.5 \mathrm{mg} / \mathrm{kg} / \mathrm{d}$ FGF-21 for 8 weeks. Hepatic mRNA analyses of

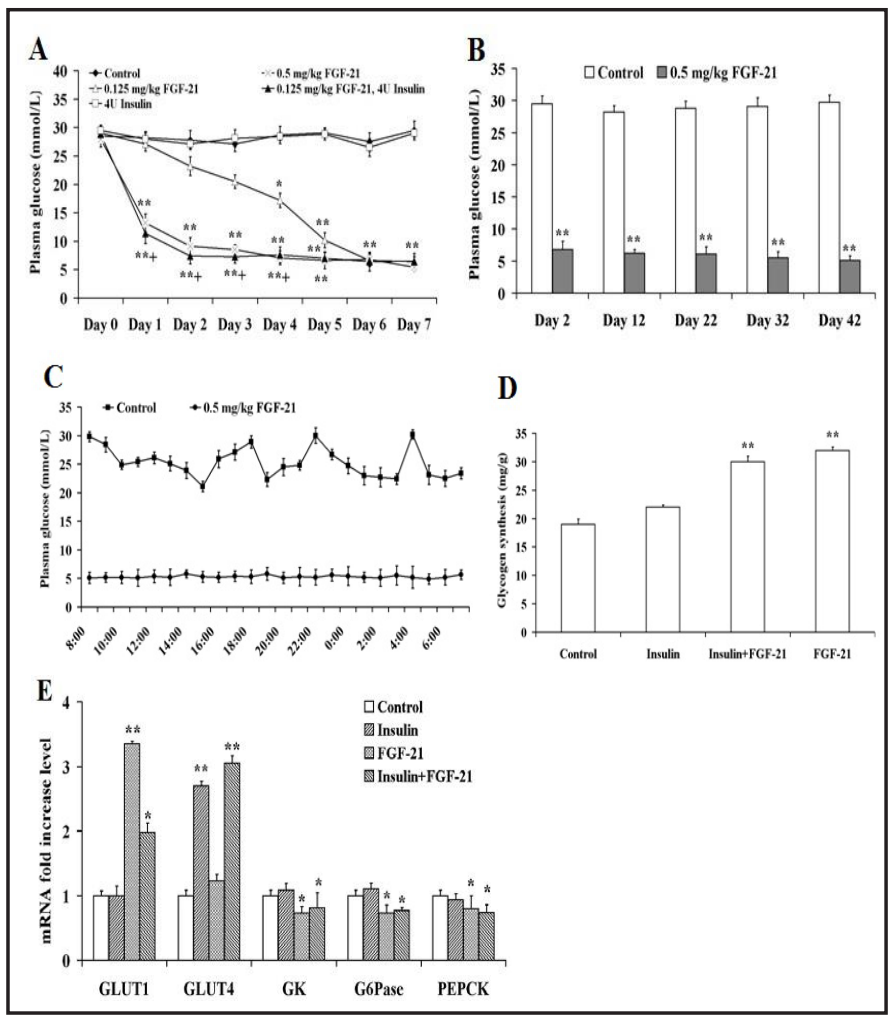
glucose transporter 1 (GLUT1), glucose transporter 4 (GLUT4), glucokinase (GK), glucose-6-phosphatase (G6Pase) and phosphoenolpyruvate carboxykinase (PEPCK) in $\mathrm{db} / \mathrm{db}$ mice via real-time PCR. The values $( \pm \mathrm{SE})$ shown are the average of at least 3 independent experiments. ${ }^{*} \mathrm{P}<0.05,{ }^{*} \mathrm{P}<0.01$ compared to unstimulated control. ${ }^{+} \mathrm{P}<0.01$ compared to the groups treated with $0.125 \mathrm{mg} / \mathrm{kg}$ FGF-21.

gene expression of GLUT1, GLUT2, GLUT3 and GLUT4 in vivo. GLUT1 and GLUT4 were increased in the liver after treatment with FGF-21 and insulin, respectively. This revealed that FGF-21 specifically induced GLUT1 mRNA up-regulation in the liver tissue to transport glucose. Taken together, our study showed that the liver is one of the important target organs of FGF-21 and plays an important role in the regulation of glucose homeostasis in diabetic mice by FGF-21 administration.

\section{Discussion}

The liver contains many enzymes to maintain plasma glucose levels by breaking down (glycogenolysis) or storing glycogen and converting non-carbohydrate precursors, such as lactate, amino acids and glycerol, to glucose (gluconeogenesis). Under fasting conditions, hepatic glucose production (HGP), which represents $90 \%$ of total glucose release, provides sufficient glucose to glucose-dependent tissues, such as the central nervous system, and at the same time regulates the plasma glucose concentration, as well. After feeding, the liver takes up a portion of ingested carbohydrates to restore glucose as glycogen. Glucose metabolism disorder in the liver is the main reason for hepatic insulin resistance and type 2 diabetes. The crucial problem of diabetes therapy is to control blood glucose. Glucose metabolism plays an important role in the development of diabetes. At present, FGF-21 is a potential drug candidate, and the biological function of FGF-21 in hepatocytes/liver is widely unknown. Badman et al. showed that hepatic fibroblast growth factor 21 is regulated by PPARalpha and is a key mediator of hepatic lipid metabolism in ketotic states [6]. Fisher et al. reported 
that FGF-21 could activate FGF signalling in isolated hepatocytes [20], while Xu et al. showed that FGF-21 could decrease glucose production in H4IIE cells [18]. Asrih et al. found that FFA impairs FGF21 action in HepG2 cells [27]. In vivo, FGF21 enhances hepatic insulin sensitivity [19], ameliorates AFLD [30], and regulates the adaptive metabolic response of the liver to prolonged fasting [21]. However, whether and how FGF-21 directly stimulates hepatocytes on glucose uptake is unclear. In contrast, we found that FGF-21 stimulated glucose uptake in HepG2 cells, as well as in mouse primary hepatocytes, in a dose-dependent manner (Fig. $1 \mathrm{~A}, \mathrm{~B})$.

To analyse the molecular mechanism of FGF-21-induced glucose uptake in hepatocytes, we investigated the direct effect of FGF-21 on mRNA and protein expression of GLUT1, GLUT2, GLUT3 and GLUT4 in HepG2 cells. Consistent with the effects of FGF-21 on 3T3-L1 adipocytes, we showed that FGF-21 induced mRNA expression of GLUT1 in HepG2 cells (Fig. 3). Furthermore, mRNA levels of GLUT1 and GLUT4 were significantly increased by the cotreatment of FGF-21 and insulin, compared to FGF-21 and insulin treatment alone. GLUT4 localized in storage vesicles responds to insulin and traffics to the cell surface to transport glucose [31]. GLUT1 must be synthesized for delivery to the cell surface or returned to the cell surface through a recycling pool [32]. The trafficking of GLUT1 and GLUT4 stimulated by FGF-21 and insulin requires further study and research. Here, we hypothesized that both GLUT1 and GLUT4 expression may help in understanding the synergistic effect of FGF-21 and insulin on glucose uptake.

Xu et al. found that FGF-21 treatment restored the glucose infusion rate and reduced clamp hepatic glucose production in DIO mice [12]. The effects of FGF-21 led us to study glucose metabolism by FGF-21 in liver cells. Glucose enters the liver cells and is phosphorylated by glucokinases (GK) to form glucose-6-phosphate (G6P). Depending on the energy requirements of the cells, G6P can be used to generate ATP via glycolysis or be metabolized to uridine diphospho-(UDP)-glucose and stored as glycogen [33]. Thus, measurement of glycogen content is a powerful tool to examine the probable metabolic responses of FGF-21 in vitro and in vivo at the same time. We discovered that the glycogen content in HepG2 cells significantly increased after FGF-21 treatment, compared to the control. Our studies demonstrated that FGF-21 binds to its receptor initiating some signalling cascades to increase glucose uptake via regulation of the glucose tranporter-1 (GLUT-1) and simultaneously participates in glycogen storage in the liver. Although several studies focused on the identification of FGF21 mediators, such as PPARalpha and leptin, the information of the FGF21-specific signalling pathway is still very limited at present [34]. FGF-21 enhances glucose uptake by hepatocytes, suppresses hepatic glucose production and increases liver glycogen in vivo. We speculated that FGF-21 controls the blood glucose concentration by promoting glucose uptake in liver cells and glycogen synthesis, as well as inhibiting glycogenolysis and gluconeogenesis. The $\mathrm{db} / \mathrm{db}$ diabetic mice were used to study the relation between FGF-21-regulated blood glucose levels and the effects of FGF-21 on glycogen synthesis, glycogenolysis and gluconeogenesis in the liver. 2-NBDG was used to detect glucose metabolism in $\mathrm{db} / \mathrm{db}$ mice, and phosphorylation of 2-NBDG was detected in both the liver and the adipose tissue. Subsequently, we showed that FGF-21 increased glycogen content and the GLUT1 mRNA level in vivo. In addition, we showed that plasma glucose was maintained at a normal level for 5 days after withdrawal of FGF-21 administration. Gene expression of GK, G6Pase and PEPCK, the key enzymes that are involved in gluconeogenesis, were down-regulated by FGF-21 in the liver.

\section{Conclusion}

In conclusion, we analysed the effects of FGF-21 on liver cells and showed that FGF21 enhances glucose uptake of liver cells and regulates plasma glucose levels in diabetic mice. Moreover, our study revealed that FGF-21 enhances glycogen content, increases gene expression of GLUT1 and suppresses gene expression of GK, G6Pase and PEPCK. Overall, these results suggest that FGF-21 may act in glycogen synthesis and gluconeogenesis in the regulation of glucose metabolism in the liver. 


\section{Cellular Physiology Cell Physiol Biochem 2018;45:1423-1433 \begin{tabular}{ll|l|l|l|l} 
DOI: 10.1159/000487568 & 2018 The Author(s). Published by S. Karger AG, Basel \\
and Biochemistry. & Publisned online: February 20, 2018 & www.karger.com/cpb \\
\cline { 2 - 3 }
\end{tabular}}

Liu et al.: FGF-21 Stimilates Liver Glucose Uptake

\section{Acknowledgements}

We thank Yixue Yu, Xianlong Ye, Yuanyuan Jiang, Hongmei Gao, Yang Han, YaKun Zhang and Wenbing Yao for their technical assistance. This work was supported by funding from National Natural Science Foundation of China (NSFC, 31200121) and "Young Talents" Project of Northeast Agricultural University (16QC27).

\section{Disclosure Statement}

No conflict of interests exists.

\section{References}

1 Kharitonenkov A, Shiyanova TL, Koester A, Ford AM, Micanovic R, Galbreath EJ, Sandusky GE, Hammond LJ, Moyers JS, Owens RA, Gromada J, Brozinick JT, Hawkins ED, Wroblewski VJ, Li DS, Mehrbod F, Jaskunas SR, Shanafelt AB: FGF-21 as a novel metabolic regulator. J Clin Invest 2005;115:1627-1635.

$>2$ Kharitonenkov A, Wroblewski VJ, Koester A, Chen YF, Clutinger CK, Tigno XT, Hansen BC, Shanafelt $\mathrm{AB}$, Etgen GJ: The metabolic state of diabetic monkeys is regulated by fibroblast growth factor-21 Endocrinology 2007;148:774-781.

-3 Li H, Fang Q, Gao F, Fan J, Zhou J, Wang X, Zhang H, Pan X, Bao Y, Xiang K, Xu A, Jia W: Fibroblast growth factor 21 levels are increased in nonalcoholic fatty liver disease patients and correlated with hepatic triglyceride. J Hepatol 2010;53:934-940.

-4 Coskun T, Bina HA, Schneider MA, Dunbar JD, Hu CC, Chen Y, Moller DE, Kharitonenkov A: FGF21 corrects obesity in mice. Endocrinology 2008;149:6018-6027.

> Zhu SL, Ren GP, Zhang ZY, Wang WF, Ye XL, Han MM, Zhao JZ, Xu TY, Liu MY, Li DS: Therapeutic effect of fibroblast growth factor 21 on hypertension induced by insulin resistance. Yao Xue Xue Bao 2013; 48:1409-1414.

6 Badman MK, Pissios P, Kennedy AR, Koukos G, Flier JS, Maratos-Flier E: Hepatic fibroblast growth factor 21 is regulated by PPARalpha and is a key mediator of hepatic lipid metabolism in ketotic states. Cell Meta 2007;5:426-437.

7 Stein S, Bachmann A, Lossner U, Kratzsch J, Bluher M, Stumvoll M, Fasshauer M: Serum levels of the adipokine FGF21 depend on renal function. Diabetes Care 2009;32:126-128.

8 Zhang X, Yeung DC, Karpisek M, Stejskal D, Zhou ZG, Liu F, Wong RL, Chow WS, Tso AW, Lam KS, Xu A: Serum FGF21 levels are increased in obesity and are independently associated with the metabolic syndrome in humans. Diabetes 2008;57:1246-1253.

-9 Wente W, Efanov AM, Brenner M, Kharitonenkov A, Koester A, Sandusky GE, Sewing S, Treinies I, Zitzer H, Gromada J: Fibroblast growth factor-21 improves pancreatic $\beta$-cell function and survival by activation of extracellular signal regulated kinase 1/2 and Akt signaling pathways. Diabetes 2006;55:2470-2478.

-10 Arner P, Pettersson A, Mitchell PJ, Dunbar JD, Kharitonenkov A, Ryde'n M: FGF21 attenuates lipolysis in human adipocytes: a possible link to improved insulin sensitivity. FEBS Lett 2008;582:1725-1730.

11 Kharitonenkov A, Shanafelt AB: Fibroblast growth factor-21 as a therapeutic agent for metabolic diseases. Bio Drugs 2008;22:37-44.

12 Xu J, Lloyd DJ, Hale C, Stanislaus S, Chen M, Sivits G, Vonderfecht S, Hecht R, Li YS, Lindberg RA, Chen JL, Jung DY, Zhang Z, Ko HJ, Kim JK, Véniant MM: FGF21 reverses hepatic steatosis, increases energy expenditure and improves insulin sensitivity in diet induced obese mice. Diabetes 2008;58:250-259.

13 Uebanso T, Taketani Y, Fukaya M, Sato K, Takei Y, Sato T, Sawada N, Amo K, Harada N, Arai H, Yamamoto H, Takeda E: Hypocaloric high-protein diet improves fatty liver and hypertriglyceridemia in sucrose fed obese rats via two pathways. Am J Physiol Endocrinol Metab 2009;297:E76-E84.

14 Berglund ED, Li CY, Bina HA, Lynes SE, Michael MD, Shanafelt AB, Kharitonenkov A, Wasserman DH: Fibroblast growth factor 21 controls glycemia via regulation of hepatic glucose flux and insulin sensetivity. Endocrinology 2009;150:4084-4093. 


\section{Cellular Physiology Cell Physiol Biochem 2018;45:1423-1433

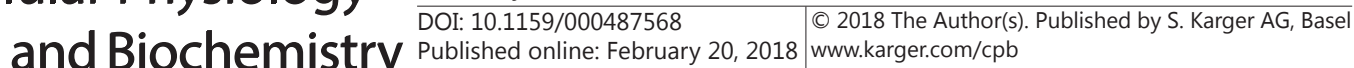

15 Postic C, Dentin R, Girard J: Role of the liver in the control of carbohydrate and lipid homeostasis. Diabetes Metab 2004;30:398-408.

-16 Nevado C, Valverde AM, Benito M: Role of insulin receptor in the regulation of glucose uptake in neonatal hepatocytes. Endocrinology 2006;147:3709-3718.

17 Cherrington AD, Edgerton D, Sindelar DK: The direct and indirect effects of insulin on hepatic glucose production in vivo. Diabetologia 1998;41:987-996.

-18 Xu J, Stanislaus S, Chinookoswong N, Lau YY, Hager T, Patel J, Ge H, Weiszmann J, Lu SC, Graham M, Busby J, Hecht R, Li YS, Li Y, Lindberg R, Véniant MM: Acute glucose-lowering and insulin-sensitizing action of FGF21 in insulin-resistant mouse models--association with liver and adipose tissue effects. Am J Physiol Endocrinol Metab 2009;297:1105-1114.

19 Gong Q Hu Z, Zhang F, Cui A, Chen X, Jiang H, Gao J, Chen X, Han Y, Liang Q, Ye D, Shi L, Chin YE, Wang Y, Xiao H, Guo F, Liu Y, Zang M, Xu A, Li Y: Fibroblast Growth Factor 21 Improves Hepatic Insulin Sensitivity by Inhibiting Mammalian Target of Rapamycin Complex 1. Hepatology 2016;64:425-438.

20 Fisher FM, Estall JL, Adams AC, Antonellis PJ, Bina HA, Flier JS, Kharitonenkov A, Spiegelman BM, MaratosFlier E: Integrated Regulation of Hepatic Metabolism By Fibroblast Growth Factor 21 (Fgf21) In vivo. Endocrinology 2011;152:2996-3004.

21 Potthoff MJ, Inagaki T, Satapati S, Ding X, He T, Goetz R, Mohammadi M, Finck BN, Mangelsdorf DJ, Kliewer SA, Burgess SC: FGF21 induces PGC-1alpha and regulates carbohydrate and fatty acid metabolism during the adaptive starvation response. Proc Natl Acad Sci USA 2009;106:10853-10858.

22 Jiang YY, Liu MY, Ren GP, Wang WF, Liu XM, Li DS: Cloning, Expression and Purification of Mouse Fibroblast Growth Factor-21 and Its Function in Adipocyte Glucose Metabolism. Prog Biochem Biophys 2009;32:157164.

23 Aiston S, Hampson L, Gomez-Foix AM, Guinovart JJ, Agius L: Hepatic glycogen synthesis is highly sensitive to phosphorylase activity: evidence from metabolic control analysis. J Biol Chem 2001;276:23856-23866.

-24 Ge TF, Law PY, Wong HY, Ho YY: Gatifloxacin affects GLUT1 gene expression and disturbs glucose homeostasis in vitro. Eur J Pharmacol 2007;573:70-74.

25 Singh V, Grotzinger C, Nowak KW, Zacharias S, Goncz E, Pless G, Sauer IM, Eichhorn I, Pfeiffer-Guglielmi B, Wiedenmann B, Plockinger U, Strowski MZ: Somatostatin receptor subtype-2-deficient mice with dietinduced obesity have hyperglycemia, nonfasting hyperglucagonemia, and decreased hepatic glycogen deposition. Endocrinology 2007;148:3887-3899.

26 Yang G. Zhu D: Glycogen assay for diagnosis of female genital Chlamydia trachomatis infection. J Clin Microbiol 1998;36:1081-1082.

27 Asrih M, Montessuit C, Philippe J, Jornayvaz FR: Free Fatty Acids Impair FGF21 Action in HepG2 Cells. Cell Physiol Biochem 2015;37:1767-1778.

28 Liu MY, Wang WF, Hou YT, Yu YX, Ren GP, Kern TS, Sun GP, Li DS: Fibroblast growth factor (FGF)-21 regulates glucose uptake through GLUT1 translocation. Afr J Microbiol Res 2012;6:2504-2511.

29 Zhao FQ Keating AF: Functional properties and genomics of glucose transporters. Curr Genomics 2007;8:113-128.

-30 Zhu S, Ma L, Wu Y, Ye X, Zhang T, Zhang Q, Rasoul LM, Liu Y, Guo M, Zhou B, Ren G, Li D: FGF21 treatment ameliorates alcoholic fatty liver through activation of AMPK-SIRT1 pathway. Acta Biochim Biophys Sin 2014;46:1041-1048.

-31 Watson RT, Kanzaki M, Pessin JE: Regulated membrane trafficking of the insulin-responsive glucose transporter 4 in adipocytes. Endocr Rev 2004;25:177-204.

-32 Wieman HL, Wofford JA and Rathmell JC: Cytokine stimulation promotes glucose uptake via Phosphatidylinositol-3 Kinase/Akt Regulation of Glut1 activity and trafficking. Mol Biol Cell 2007;18:14371446.

33 DeFronzo RA, Bonadonna RC, Ferrannini E: Pathogenesis of NIDDM. A balanced overview. Diabetes Care 1992;15:318-368.

34 Asrih M, Veyrat-Durebex C, Poher AL, Lyautey J, Rohner-Jeanrenaud F, Jornayvaz FR: Leptin as a Potential Regulator of FGF21. Cell Physiol Biochem 2016;38:1218-25. 